\title{
LATERAL-TORSIONAL BUCKLING OF BEAMS ELASTICALLY RESTRAINED AGAINST WARPING AT SUPPORTS
}

\section{R. PIOTROWSKI ${ }^{1}$, A. SZYCHOWSKI ${ }^{2}$}

\begin{abstract}
The study presents the results of theoretical investigations into lateral torsional buckling (LTB) of bi-symmetric I-beams, elastically restrained against warping at supports. Beam loading schemes commonly used in practice are taken into account. The whole range of stiffness of the support joints, from free warping to warping fully restrained, is considered. To determine the critical moment, the energy method is used. The function of the beam twist angle is described with power polynomials that have simple physical interpretation. Computer programs written in symbolic language for numerical analysis are developed. General approximation formulas are devised. Detailed calculations are performed for beams with end-plate joints. Critical moments determined with programs and approximation formulas are compared with the results obtained by other researchers and with those produced by FEM. Very good accuracy of results is obtained.
\end{abstract}

Keywords: critical moment for lateral torsional buckling (LTB), elastic end section restraint against warping, end-plates, the energy method, power polynomials

\footnotetext{
${ }^{1}$ MSc Eng., Kielce University of Technology, Faculty of Civil Engineering and Architecture, Al. 1000-lecia PP 7 , 25-314 Kielce, Poland, e-mail: rafalp@tu.kielce.pl.

${ }^{2}$ PhD Eng., Kielce University of Technology, Faculty of Civil Engineering and Architecture, Al. 1000-lecia PP 7, 25-314 Kielce, Poland, e-mail: aszychow@tu.kielce.pl.
} 


\section{INTRODUCTION}

Presently used methods of steel member design tend to account for a number of parameters that improve the way how real boundary conditions of structural members are represented in the engineering computational model. The effect of the support elastic restraint against warping on the critical moment is one of relevant parameters.

The literature on LTB, which is vast, deals with many aspects of this phenomenon. For instance, the formulas necessary to determine the elastic critical moment of beams with fork support are given, among others, in studies $[1,3,4,16]$. The formulas account for effect produced by the height, at which one type of the transverse load is applied, with respect to the section shear centre. Bijak in study [1] provided the critical moment formula, in which a few different load types and varied ordinates of load application over the beam section height were taken into consideration.

In addition to classic solutions for fork support, some studies, including [5,7,8,10,11,12], analyse the effect of the stiffness of the elastic restraint against warping at the site of the beam support. In those studies, it was theoretically demonstrated and experimentally verified that increase in the stiffness of the support sections preventing warping causes an increase in the critical moment of the beam. Different rib configurations intended to constrain warping in support sections were presented, e.g. in $[6,12]$.

The present study deals with LTB of bi-symmetric I-beams, elastically restrained against warping at supports. The energy method is used to determine the critical moments [16]. The function of the twist angle is approximated by power polynomials. The computational program and approximation formulas for the estimation of the elastic critical moment are developed. Computations are performed for basic, most frequently found loading schemes. Detailed calculations are performed for beams stiffened with end-plates. The results obtained are compared with FEM values (LTBeam [4] and Abaqus software).

\section{CRITICAL MOMENT OF THE BEAM STIFFENED WITH END-PLATES}

In study [10], Lindner presented Eq. (2.1) for the elastic critical moment of the beam simply supported against bending, which accounted for the stiffening against warping by using the endplates (Fig. 1): 


$$
M_{k i}=\zeta \frac{E I_{z} \pi^{2}}{L^{2}}\left(\sqrt{\frac{1}{I_{z}}\left(\frac{I_{\omega}}{\beta_{0}^{2}}+\frac{G I_{t} L^{2}}{E \pi^{2}}\right)+\left(\frac{5 z_{g}}{\pi^{2}}\right)^{2}}+\frac{5 z_{g}}{\pi^{2}}\right)
$$

where: $\zeta$ - coefficient dependent on the bending moment distribution [2],

$z_{g}$ - ordinate of the site, at which load is applied, over the section height,

$\beta_{0}$ - coefficient of the torsional buckling length, acc. Eq. (2.2),

$$
\beta_{0}=1-\frac{0.5}{1+\frac{2 E I_{\omega}}{c_{w} L}}
$$

where: $c_{w}$ - St. Venant stiffness of the end-plate, acc. Eq. (2.3),

$$
c_{w}=\frac{1}{3} G t_{p}^{3} b\left(h-t_{f}\right)
$$

where: $t_{p}, b$ - thickness and width of end-plate (Fig. 1),

$h, t_{f}$ - height of the beam section, thickness of the beam flange (Fig. 1).

a)

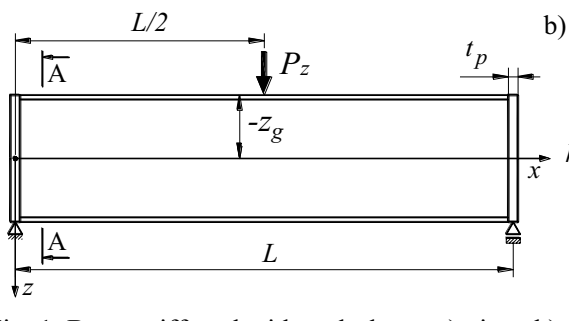

Fig. 1. Beam stiffened with end-plates: a) view, b) section A-A

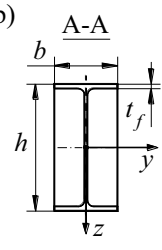

Critical moments computed on the basis of Eq. (2.1) for specific cases were compared with FEM results in Chapter 8 . 


\section{DEGREE OF ELASTIC RESTRAINT AGAINST WARPING}

The degree of elastic restraint against warping can be described with coefficient $\varepsilon[8,12]$ according to Eq. (3.1):

$$
\varepsilon=\frac{\alpha_{w} L}{E I_{w}}
$$

where: $\alpha_{w}$ - stiffness of the elastic restraint [8,12], acc. Eq. (3.2):

$$
\alpha_{w}=-\frac{B}{d \varphi / d x}
$$

where: $B$ - bimoment at the site of the beam support; $d \varphi / d x$ - warping in the support section.

Elastic restraint coefficient $\varepsilon$ acc. Eq. (3.1) ranges from $\varepsilon=0$, for the end free to warp, to $\varepsilon=\infty$, for warping fully restrained.

Formulas for the estimation of the stiffness of the elastic restraint $\left(\alpha_{w}\right)$, depending on how the beam is stiffened at its support, can be found, among others, in $[6,12]$. The stiffening types that are most often analysed are presented in Table 1. It should be noted that for the sake of comparison, No. 1 was used to mark the beam end without any stiffening.

Table 1. Exemplary ways of beam stiffening used to prevent warping [6,12]

\begin{tabular}{|l|l|l|l|l|l|}
\hline Item & Scheme of stiffening & Item & Scheme of stiffening & Item & Scheme of stiffening \\
\hline & & & & &
\end{tabular}


In the present study, the dimensionless fixity factor $\kappa$ was derived, acc. Eq. (3.3):

$$
\kappa=\frac{\alpha_{w} L}{2 E I_{w}+\alpha_{w} L}
$$

which ranges from $\kappa=0$, for the end free to warp, to $\kappa=1$, for warping fully restrained. Known dependences between the coefficient $\varepsilon$ and factor $\kappa$, are given by Eq. (3.4) [15]:

$$
\kappa=\frac{\varepsilon}{2+\varepsilon} ; \quad \varepsilon=\frac{2 \kappa}{1-\kappa}
$$

\section{FUNCTION OF THE BEAM TWIST ANGLE}

In the majority of studies available in literature, e.g. in [1,16], trigonometric series were employed to approximate the function of the beam twist angle. Compared with FEM (LTBeam) [4], for symmetric or slightly asymmetric loads (with respect to the beam transverse axis) good results were obtained, e.g. [1], already when the first term of the sine series was used.

Another approach was proposed in study [13], where power polynomials were successfully applied to the approximation of the function of the beam twist angle.

In Poland, the idea of using polynomials in the stability analysis of thin-walled members was promoted by Jakubowski's studies, e.g. [9]. Also, power polynomials were used to determine buckling state of thin-walled bars with open section subjected to warping torsion [14].

In the present paper, the function of the beam twist angle is approximated with the series:

$$
\varphi(x)=\sum_{i=1}^{3} a_{i}\left((1-\kappa) W_{P i}+\kappa W_{U i}\right)
$$

where: $a_{i}$ - free parameters of the twist angle function; $\kappa$ - fixity factor acc. to Eq. (3.3); $W_{P_{i}}$ - polynomials describing the "deflection" function of the simply supported beam; $W_{U i}$ - polynomials describing the "deflection" function of the restrained beam.

The power polynomials $\left(W_{P i}, W_{U i}\right)$ and their physical interpretation are presented in Table 2 (where $\rho=x / L)$. 
Table 2. Polynomials used in the study $(\rho=x / L)$

\begin{tabular}{|c|c|c|}
\hline Item & Polynomials & Physical interpretation \\
\hline 1 & 2 & 3 \\
\hline 1 & $W_{P 1}=\rho-2 \rho^{3}+\rho^{4}$ & 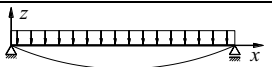 \\
\hline 2 & $W_{P 2}=\rho-10 \rho^{3}+15 \rho^{4}-6 \rho^{5}$ & $\mathrm{Az}$ \\
\hline 3 & $W_{P 3}=\rho-26 \rho^{3}+73 \rho^{4}-72 \rho^{5}+24 \rho^{6}$ & ${ }^{z}>$ \\
\hline 4 & $W_{U 1}=\rho^{2}-2 \rho^{3}+\rho^{4}$ & 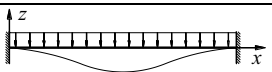 \\
\hline 5 & $W_{U 2}=\rho^{2}-4 \rho^{3}+5 \rho^{4}-2 \rho^{5}$ & $|z|+1+11 \mid x$ \\
\hline 6 & $W_{U 3}=2 \rho^{2}-13 \rho^{3}+29 \rho^{4}-27 \rho^{5}+9 \rho^{6}$ & $t^{z} \bigcirc$ \\
\hline
\end{tabular}

Polynomials, adopted for the twist angle function satisfy the boundary conditions, respectively free warping $W_{P i}\left(\varphi=0, \varphi^{\prime \prime}=0\right.$ for $x=0$ and $\left.x=L\right)$ and warping fully restrained $W_{U i}\left(\varphi=0, \varphi^{\prime}=0\right.$ for $x=0$ and $x=L)$.

The twist angle function applied, Eq. (4.1), together with polynomials $\left(W_{P i}\right.$ and $\left.W_{U i}\right)$ listed in Table 2 make it possible to model elastic restraint against warping for an arbitrary value of the fixity factor in the range: $0<\kappa<1$.

\section{DETERMINATION OF THE CRITICAL MOMENT WITH USING THE ENERGY METHOD}

The energy method [16] is used herein to determine the elastic critical moment of simply supported, bi-symmetric I-beam, where the elastic restrain against warping at the support is taken into account. The critical value of the load is determined from Eq. (5.1):

$$
\Delta \Pi=\Delta U_{s, 1}+\Delta U_{s, 2}-\Delta T
$$

where: $\Delta U_{s, 1}$ - elastic energy of the beam bending and torsion; $\Delta U_{s, 2}$ - energy of the elastic restraint against warping at the support sections; $\Delta T$ - the work done by external forces. 
The elastic energy of the beam bending and torsion is expressed by Eq. (5.2) acc. [16]:

$$
\Delta U_{s, 1}=\frac{1}{2}\left(E I_{z} \int_{0}^{L}\left(\frac{d^{2} u}{d x^{2}}\right)^{2} d x+G I_{t} \int_{0}^{L}\left(\frac{d \varphi}{d x}\right)^{2} d x+E I_{\omega} \int_{0}^{L}\left(\frac{d^{2} \varphi}{d x^{2}}\right)^{2} d x\right)
$$

The energy of the beam elastic restraint against warping is determined acc. Eq. (5.3):

$$
\Delta U_{s, 2}=\frac{\alpha_{w}}{2}\left(\left(\frac{d \varphi}{d x}\right)_{x=0}^{2}+\left(\frac{d \varphi}{d x}\right)_{x=L}^{2}\right)
$$
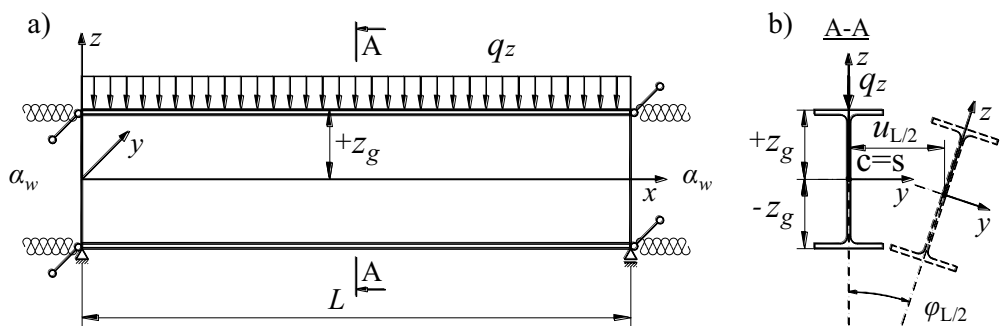

Fig. 2. Static scheme of the beam: a) view, b) section A-A

The work done by external forces is a function of the loading scheme and the coordinate of the point, at which load is applied. For instance, for the beam that is simply supported (in the $x z$ plane) (Fig. 2), and under uniformly distributed load, at arbitrary coordinate of the load application point $\left(z_{g}\right)$ over the section height, the work done by external forces can be written as Eq. (5.4):

$$
\Delta T=\frac{q_{z}}{2}\left(\int_{0}^{L} \varphi \frac{d^{2} u}{d x^{2}}(L-x) x d x+z_{g} \int_{0}^{L} \varphi^{2} d x\right)
$$

In Eq. (5.2) and (5.4), the function of lateral displacement (u) with respect to the $z$ axis (Fig. 2) and twist angle function $(\varphi)$ are found. To be able to describe the beam behaviour with one function $(\varphi)$, Eq. (5.5) of the warped beam [16] is used:

$$
E I_{z} \frac{d^{2} u}{d x^{2}}=M_{z}
$$


Using Eq. (5.1) and the twist angle function Eq. (4.1), together with polynomials given in Table 2, the computational program McrLT_elastic_fix.on.warp.nb., termed $M_{L T B, E L}$, is developed using Mathematica ${ }^{\circledR}$ software package. The program makes it possible to determine critical moments for arbitrary geometric parameters of bi-symmetric I-sections, the loading schemes presented in Tables 3,4 and 5, an arbitrary value of the coordinate $\left(z_{g}\right)$ (Fig. 2) of the point, at which transverse load is applied (Table 4), and for an arbitrary value of the fixity factor $\kappa$, Eq. (3.3).

Exemplary specific cases, computed with $M_{L T B, E L}$ program, are presented in Chapter 8.

\section{APPROXIMATION FORMULAS}

In study [13], on the basis of symbolic calculations, simple approximation formulas were derived for the critical moment of bi-symmetric I-beams with fork support (i.e., having free warping conditions at supports). To do that, only the first term in the twist angle function Eq. (4.1) and one polynomial ( $W_{P 1}$, No. 1 from Table 2) were used. A very good agreement between the results obtained in that way, and those produced by FEM (LTBeam) was achieved.

Like in [13], in the present study, the program McrLT_elastic_fix.on.warp._sym.cal.nb is developed, using Mathematica ${ }^{\circledR}$ software package, to perform symbolic calculations. The twist angle function is approximated, as previously, employing only the first term of the series Eq. (4.1) with use of polynomials: $W_{P 1}$ and $W_{U 1}$ (Table 2). That makes it possible to derive relatively simple approximation formulas Eq. (6.1), (6.2), and (6.3) for critical moments of beams with bi-symmetric I sections, elastically restrained against warping.

For the load applied to the section shear centre, and for the loading schemes presented in Table 3, it is obtained:

$$
M_{c r}=\frac{\sqrt{E I_{z}\left(A_{1} G I_{t} L^{2}+A_{2} E I_{\omega}\right)}}{A_{3} L^{2}}
$$

where: $A_{1}, A_{2}, A_{3}$ - coefficients (Table 3). 
Table 3. Coefficients $A_{1}, A_{2}, A_{3}$ for selected loading schemes

\begin{tabular}{|c|c|c|}
\hline Item & Static scheme & Coefficients \\
\hline 1 & 2 & 3 \\
\hline 1 & $\frac{\downarrow^{P_{z}}}{\boldsymbol{L}}=$ & $\begin{array}{c}A_{1}=19.28 \cdot\left(1.457-2.4 \kappa+\kappa^{2}\right) \\
A_{2}=231.366 \cdot(1.2-\kappa) \\
A_{3}=\sqrt{1.522-2.467 \kappa+\kappa^{2}}\end{array}$ \\
\hline 2 & 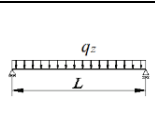 & $\begin{array}{c}A_{1}=13.109 \cdot\left(1.457-2.4 \kappa+\kappa^{2}\right) \\
A_{2}=157.308 \cdot(1.2-\kappa) \\
A_{3}=\sqrt{1.507-2.455 \kappa+\kappa^{2}}\end{array}$ \\
\hline 3 & $q_{-1}^{q_{z}}$ & $\begin{array}{c}A_{1}=13.628 \cdot\left(1.457-2.4 \kappa+\kappa^{2}\right) \\
A_{2}=163.538 \cdot(1.2-\kappa) \\
A_{3}=\sqrt{1.507-2.455 \kappa+\kappa^{2}}\end{array}$ \\
\hline
\end{tabular}

When arbitrary ordinate of the load application with respect to the shear centre of the beam section is taken into consideration, the critical moment formula is as follows Eq. (6.2):

$$
M_{c r}=\frac{-B_{1} E I_{z} z_{g}+\sqrt{E I_{z}\left(B_{3} G I_{t} L^{2}+B_{4} E I_{\omega}+B_{1}^{2} E I_{z} z_{g}^{2}\right)}}{B_{2} L^{2}}
$$

where: $B_{1}, B_{2}, B_{3}, B_{4}$ - coefficients (Table 4); $z_{g}$ - ordinate of the load application.

Table 4. Coefficients $B_{1}, B_{2}, B_{3}, B_{4}$ for selected loading schemes

\begin{tabular}{|c|c|c|}
\hline Item & Static scheme & Coefficients \\
\hline 1 & 2 & 3 \\
\hline 1 & $\frac{b^{P_{z}}}{L}=$ & $\begin{array}{c}B_{1}=7.242 \cdot\left(1.563-2.5 \kappa+\kappa^{2}\right) \\
B_{2}=1.522-2.467 \kappa+\kappa^{2} \\
B_{3}=19.248 \cdot B_{2}\left(1.457-2.4 \kappa+\kappa^{2}\right) \\
B_{4}=231.816 \cdot B_{2}(1.2-\kappa)\end{array}$ \\
\hline 2 & 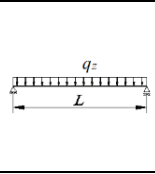 & $\begin{array}{c}B_{1}=5.25 \cdot\left(1.476-2.429 \kappa+\kappa^{2}\right) \\
B_{2}=1.507-2.455 \kappa+\kappa^{2} \\
B_{3}=13.092 \cdot B_{2}\left(1.457-2.4 \kappa+\kappa^{2}\right) \\
B_{4}=157.633 \cdot B_{2}(1.2-\kappa)\end{array}$ \\
\hline 3 & $\frac{q_{z}}{L}$ & $\begin{array}{c}B_{1}=5.322 \cdot\left(1.476-2.429 \kappa+\kappa^{2}\right) \\
B_{2}=1.507-2.455 \kappa+\kappa^{2} \\
B_{3}=13.624 \cdot B_{2}\left(1.457-2.4 \kappa+\kappa^{2}\right) \\
B_{4}=163.486 \cdot B_{2}(1.2-\kappa)\end{array}$ \\
\hline
\end{tabular}

For the beam loaded by moments concentrated at supports (Table 5), the formula for the critical moment takes the form given by Eq. (6.3): 


$$
M_{c r}=\sqrt{\frac{E I_{z}\left(C_{1} G I_{t} L^{2}+C_{2} E I_{\omega}\right)}{C_{3} L^{4}\left(1+C_{4} \psi+\psi^{2}\right)}}
$$

where: $\psi$ - ratio of concentrated support moments (from 0 to 1 ); $C_{1}, C_{2}, C_{3}, C_{4}$ - coefficients (Table 5).

Table 5. Coefficients $C_{1}, C_{2}, C_{3}, C_{4}$

\begin{tabular}{|c|c|c|}
\hline Item & Static scheme & Coefficients \\
\hline 1 & 2 & 3 \\
\hline & $M_{2}$ & $C_{1}=35 \cdot\left(1.457-2.4 \kappa+\kappa^{2}\right)$ \\
& - & $C_{2}=420 \cdot(1.2-\kappa)$ \\
1 & $\psi$ & $C_{3}=1.462-2.417 \kappa+\kappa^{2}$ \\
& $\psi$ & $C_{4}=1.5 \cdot\left(1.495-2.444 \kappa+\kappa^{2}\right) / C_{3}$ \\
\hline
\end{tabular}

When no stiffening against beam warping is found at the support $(\kappa=0)$, formulas in Eq. (6.1), (6.2), (6.3) are reduced to those presented in study [13].

\section{FEM VERIFICATION USING LTBEAM AND ABAQUS}

To verify numerical calculations obtained with the $M_{L T B, E L}$ program and analytical results from approximation formulas (6.2), (6.3) numerical analyses FEM are performed using LTBeam and Abaqus software.

LTBeam [4] is a widely known, free licence program, which allows engineers to determine critical moments of arbitrary I-beams with mono- or bi-symmetric sections. The program makes it possible to assume classical boundary conditions (fork support), and also to account for the beam stiffening at the support (including restraint of section warping). It should be noted, however, that in the LTBeam version 1.0.11, which is employed in the paper, errors were revealed in the representation of the units of the elastic restraint $\theta^{\prime}$. That may lead to incorrect formulation of the warping stiffness, thus to incorrect estimation of the critical moment.

Abaqus advanced package software, based on FEM, is used mainly for research purposes. In this study, it is used for the LTB analysis of exemplary beams stiffened with end-plates. In modelling, volumetric elements (C3D8) with eight nodes and six degrees of freedom in the node are used. The beam models are discretized, with the mesh size of $10 \mathrm{~mm}$. Boundary conditions at the supports prevent displacements with respect to the principal axes of the section inertia, and along the 
longitudinal axis for one of the supports. The load is applied to the top flange of the beam. Computations are performed for the elastic range.

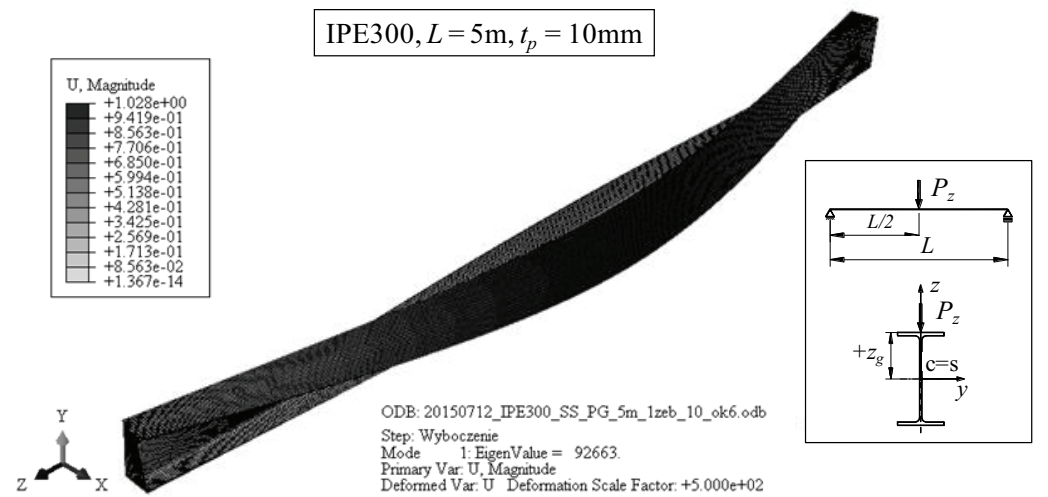

Fig. 3. Exemplary beam modelled using the Abaqus software

\section{COMPUTATIONAL EXAMPLES}

The analysis is applied to the beam section IPE500 $\left(I_{z}=2140 \mathrm{~cm}^{4}, I_{\omega}=1249000 \mathrm{~cm}^{6}, I_{t}=91.9 \mathrm{~cm}^{4}\right.$, $E=210 \mathrm{GPa}, G=81 \mathrm{GPa}$ ), having the span of $L=8 \mathrm{~m}$.

Table 6 presents the comparison of the values of critical moments ( $M_{L T B, E L}$ vs. Eq. (6.2) vs. LTBeam) determined for the loading schemes in Column 2. The critical moment values are calculated for different values $(0,0.25,0.5,0.75$ and 1$)$ of the fixity factor $(\kappa)$, i.e. ranging from 0 (free warping) to 1 (warping fully restrained). The load is applied at the characteristic points of the beam section (top flange, shear centre, bottom flange). Column 8 shows the percentage differences between moments estimated from Eq. (6.2) and the values obtained using LTBeam (FEM) (Columns 5 and 7).

The results in Table 6 show that elastic critical moments, estimated with Eq. (6.2), give sufficient engineering approximation when compared with FEM (differences ranging from +0.1 to $+1.4 \%$, Column 8). The use of the first three terms of the series Eq. (4.1) in the $M_{L T B, E L}$ program produced the results that differed from FEM not more than $-0.6 \%$ to $+0.4 \%$ (Columns 5 and 6 ). It should be noted that the results in Column 7 can also be used to verify the correctness of the formula Eq. (6.2) when it is implemented in a spreadsheet. 
Table 6. Comparison of critical moments ( $M_{L T B, E L}$ vs. Eq. (6.2) vs. LTBeam)

\begin{tabular}{|c|c|c|c|c|c|c|c|}
\hline \multirow[b]{2}{*}{ Item } & \multirow{2}{*}{$\begin{array}{c}\text { Static } \\
\text { scheme }\end{array}$} & \multirow[b]{2}{*}{$\kappa$} & \multirow[b]{2}{*}{$\begin{array}{c}z_{g} \\
{[\mathrm{~cm}]}\end{array}$} & \multicolumn{4}{|c|}{ Mcr [kNm] } \\
\hline & & & & LTBeam & $M_{L T B, E L}$ & $\begin{array}{c}\text { Formula } \\
(6.2)\end{array}$ & $\%$ \\
\hline 1 & 2 & 3 & 4 & 5 & 6 & 7 & 8 \\
\hline \multirow{15}{*}{1} & \multirow{15}{*}{$P_{z}$} & \multirow{3}{*}{0} & 25 & 272.90 & 273.70 & 276.82 & 1.4 \\
\hline & & & 0 & 384.12 & 384.29 & 385.89 & 0.5 \\
\hline & & & -25 & 537.44 & 538.09 & 537.93 & 0.1 \\
\hline & & \multirow{3}{*}{0.25} & 25 & 286.85 & 287.68 & 290.89 & 1.4 \\
\hline & & & 0 & 399.54 & 399.71 & 401.35 & 0.4 \\
\hline & & & -25 & 553.22 & 553.86 & 553.76 & 0.1 \\
\hline & & \multirow{3}{*}{0.5} & 25 & 309.05 & 309.97 & 313.30 & 1.4 \\
\hline & & & 0 & 424.07 & 424.26 & 425.96 & 0.4 \\
\hline & & & -25 & 578.52 & 579.13 & 579.13 & 0.1 \\
\hline & & \multirow{3}{*}{0.75} & 25 & 350.31 & 351.39 & 354.88 & 1.3 \\
\hline & & & 0 & 469.57 & 469.79 & 471.62 & 0.4 \\
\hline & & & -25 & 625.91 & 626.50 & 626.78 & 0.1 \\
\hline & & \multirow{3}{*}{1} & 25 & 456.05 & 457.87 & 461.06 & 1.1 \\
\hline & & & 0 & 586.24 & 586.74 & 588.94 & 0.5 \\
\hline & & & -25 & 749.94 & 750.49 & 752.30 & 0.3 \\
\hline \multirow{15}{*}{2} & \multirow{15}{*}{ 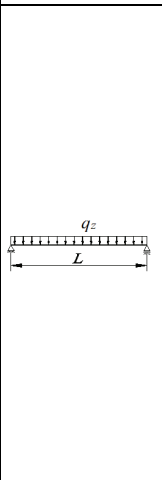 } & \multirow{3}{*}{0} & 25 & 241.83 & 241.82 & 242.05 & 0.1 \\
\hline & & & 0 & 319.19 & 319.16 & 319.82 & 0.2 \\
\hline & & & -25 & 420.92 & 420.92 & 422.58 & 0.4 \\
\hline & & \multirow{3}{*}{0.25} & 25 & 254.91 & 254.90 & 255.15 & 0.1 \\
\hline & & & 0 & 332.40 & 332.38 & 333.06 & 0.2 \\
\hline & & & -25 & 433.13 & 433.11 & 434.75 & 0.4 \\
\hline & & \multirow{3}{*}{0.5} & 25 & 275.93 & 275.92 & 276.24 & 0.1 \\
\hline & & & 0 & 353.54 & 353.53 & 354.25 & 0.2 \\
\hline & & & -25 & 452.71 & 452.68 & 454.30 & 0.3 \\
\hline & & \multirow{3}{*}{0.75} & 25 & 315.53 & 315.51 & 316.09 & 0.2 \\
\hline & & & 0 & 393.09 & 393.07 & 394.01 & 0.2 \\
\hline & & & -25 & 489.45 & 489.46 & 491.13 & 0.3 \\
\hline & & \multirow{3}{*}{1} & 25 & 420.31 & 420.34 & 423.08 & 0.7 \\
\hline & & & 0 & 496.63 & 496.70 & 499.49 & 0.6 \\
\hline & & & -25 & 586.72 & 586.81 & 589.68 & 0.5 \\
\hline \multirow{15}{*}{3} & \multirow{15}{*}{$\begin{array}{l}q_{z} \\
\underline{L} \\
L\end{array}$} & & 25 & 245.98 & 246.61 & 247.15 & 0.5 \\
\hline & & 0 & 0 & 325.53 & 324.78 & 326.06 & 0.2 \\
\hline & & & -25 & 429.74 & 427.05 & 430.16 & 0.1 \\
\hline & & & 25 & 259.27 & 259.93 & 260.48 & 0.5 \\
\hline & & 0.25 & 0 & 339.01 & 338.24 & 339.52 & 0.2 \\
\hline & & & -25 & 442.24 & 439.48 & 442.55 & 0.1 \\
\hline & & & 25 & 280.70 & 281.35 & 281.94 & 0.4 \\
\hline & & 0.5 & 0 & 360.58 & 359.77 & 361.09 & 0.1 \\
\hline & & & -25 & 462.29 & 459.44 & 462.44 & 0.0 \\
\hline & & & 25 & 321.07 & 321.70 & 322.51 & 0.4 \\
\hline & & 0.75 & 0 & 400.98 & 400.07 & 401.54 & 0.1 \\
\hline & & & -25 & 499.93 & 497.00 & 499.95 & 0.0 \\
\hline & & & 25 & 428.33 & 428.67 & 431.45 & 0.7 \\
\hline & & 1 & 0 & 506.95 & 505.90 & 508.93 & 0.4 \\
\hline & & & -25 & 599.54 & 596.72 & 600.33 & 0.1 \\
\hline
\end{tabular}

Table 7 lists the values of critical moments ( $M_{L T B, E L}$ vs. Eq. (6.3) vs. LTBeam) determined for the linear distribution of the bending moment resulting from concentrated support moments at different 
values of the fixity factor ( $\kappa$ ) (from 0 to 1 ) and coefficient ( $\psi$ ) (ranging from 0 to 1). Column 8 gives percentage differences between moments estimated with Eq. (6.3) and the values obtained with LTBeam (FEM) (Columns 5 and 7).

Table 7. Comparison of critical moments ( $M_{L T B, E L}$ vs. Eq. (6.3) vs. LTBeam)

\begin{tabular}{|c|c|c|c|c|c|c|c|}
\hline \multirow[b]{2}{*}{ Item } & \multirow[b]{2}{*}{ Static scheme } & \multirow[b]{2}{*}{$\kappa$} & \multirow[b]{2}{*}{$\psi$} & \multicolumn{4}{|c|}{$\operatorname{Mcr}[\mathrm{kNm}]$} \\
\hline & & & & LTBeam & $M_{L T B, E L}$ & $\begin{array}{c}\text { Formula } \\
(6.3)\end{array}$ & $\%$ \\
\hline 1 & 2 & 3 & 4 & 5 & 6 & 7 & 8 \\
\hline \multirow{30}{*}{1} & \multirow{30}{*}{${ }_{-L}^{M} S_{-}^{\psi M}$} & \multirow{5}{*}{0} & 1 & 282.17 & 282.17 & 282.25 & 0.0 \\
\hline & & & 0.75 & 321.81 & 321.82 & 322.14 & 0.1 \\
\hline & & & 0.5 & 372.07 & 372.11 & 373.61 & 0.4 \\
\hline & & & 0.25 & 436.13 & 436.20 & 441.25 & 1.2 \\
\hline & & & 0 & 516.69 & 516.84 & 530.59 & 2.6 \\
\hline & & \multirow{5}{*}{0.2} & 1 & 291.66 & 291.66 & 291.72 & 0.0 \\
\hline & & & 0.75 & 332.61 & 332.64 & 332.96 & 0.1 \\
\hline & & & 0.5 & 384.58 & 384.62 & 386.19 & 0.4 \\
\hline & & & 0.25 & 450.84 & 450.90 & 456.22 & 1.2 \\
\hline & & & 0 & 534.18 & 534.32 & 548.92 & 2.7 \\
\hline & & \multirow{5}{*}{0.4} & 1 & 305.27 & 305.28 & 305.33 & 0.0 \\
\hline & & & 0.75 & 348.17 & 348.18 & 348.50 & 0.1 \\
\hline & & & 0.5 & 402.59 & 402.61 & 404.27 & 0.4 \\
\hline & & & 0.25 & 471.95 & 472.04 & 477.77 & 1.2 \\
\hline & & & 0 & 559.39 & 559.54 & 575.35 & 2.8 \\
\hline & & \multirow{5}{*}{0.6} & 1 & 326.54 & 326.57 & 326.60 & 0.0 \\
\hline & & & 0.75 & 372.44 & 372.47 & 372.79 & 0.1 \\
\hline & & & 0.5 & 430.69 & 430.75 & 432.56 & 0.4 \\
\hline & & & 0.25 & 505.10 & 505.19 & 511.52 & 1.3 \\
\hline & & & 0 & 599.06 & 599.25 & 616.89 & 2.9 \\
\hline & & \multirow{5}{*}{0.8} & 1 & 364.81 & 364.82 & 364.84 & 0.0 \\
\hline & & & 0.75 & 416.11 & 416.13 & 416.48 & 0.1 \\
\hline & & & 0.5 & 481.38 & 481.43 & 483.48 & 0.4 \\
\hline & & & 0.25 & 565.03 & 565.16 & 572.45 & 1.3 \\
\hline & & & 0 & 671.39 & 671.72 & 692.37 & 3.0 \\
\hline & & \multirow{5}{*}{1} & 1 & 455.72 & 455.75 & 455.87 & 0.0 \\
\hline & & & 0.75 & 520.02 & 520.04 & 520.56 & 0.1 \\
\hline & & & 0.5 & 602.45 & 602.54 & 605.10 & 0.4 \\
\hline & & & 0.25 & 709.78 & 710.02 & 718.97 & 1.3 \\
\hline & & & 0 & 850.04 & 850.62 & 876.88 & 3.1 \\
\hline
\end{tabular}

The results in Table 7 show that the elastic critical moments, estimated using Eq. (6.3), produce sufficient engineering approximation in comparison with FEM (maximum differences are up to $+3.1 \%$, Column 8). When the full $M_{L T B, E L}$ program and three terms of the series Eq. (4.1) are used the differences do not exceed $+0.2 \%$ (Columns 5 and 6 ).

In further examples, the effect of the stiffening of the end-plates $\left(t_{p}\right)$ against warping at the beam support, on the critical moment is analysed. Calculations are made acc. Eq. (2.1) [10], acc. Eq. (6.2), and using FEM (LTBeam, Abaqus). Factor $\kappa$ is determined from Eq. (3.3) by calculating coefficient 
$\alpha_{w}$ from Eq. (3.2). In calculations, two beams are assumed, namely beam section IPE300 $\left(I_{z}=604 \mathrm{~cm}^{4}, I_{\omega}=125900 \mathrm{~cm}^{6}, I_{t}=20.7 \mathrm{~cm}^{4}, E=210 \mathrm{GPa}, G=81 \mathrm{GPa}\right)$ with the lengths of $L=5,6$ and $7 \mathrm{~m}$ and beam IPE500 $\left(I_{z}=2140 \mathrm{~cm}^{4}, I_{\omega}=1249000 \mathrm{~cm}^{6}, I_{t}=91.9 \mathrm{~cm}^{4}, E=210 \mathrm{GPa}, G=81 \mathrm{GPa}\right)$ with the lengths of $L=8,9$ and $10 \mathrm{~m}$.

Figure 4 presents the graphs of the values of the critical moment determined for beam IPE300 under concentrated load applied to the top flange at the mid span. The highest critical moments are obtained from Eq. (2.1) [10], conversely, the lowest are produced using LTBeam (FEM) and Eq. (6.2), the difference with respect to LTBeam does not exceed $+1.5 \%$. For instance, for the beam with the span of $L=5 \mathrm{~m}$ and the end-plate $t_{p}=20 \mathrm{~mm}$, Eq. (2.1) produces the critical moment that is $+5.6 \%$ greater than the LTBeam (FEM) values. For the same parameters, the difference between Eq. (6.2) and LTBeam is $+1.4 \%$, whereas between Abaqus and LTBeam, it is $+4.7 \%$.

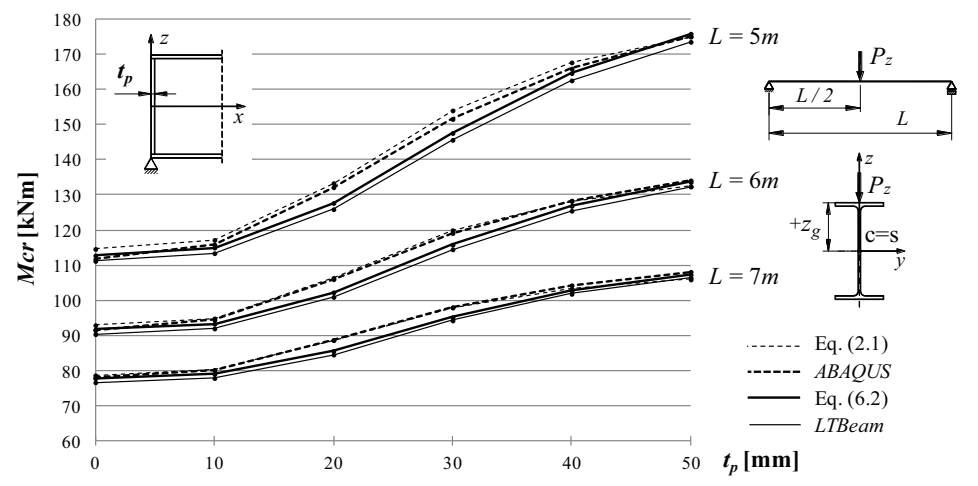

Fig. 4. Comparison of the critical moments for IPE300 beam with the span of $L=5,6,7 \mathrm{~m}$

In this case, the comparison of the results indicates that greatest positive impact on the critical moment is found for $t_{p}$ above $10 \div 20 \mathrm{~mm}$ up to $40 \mathrm{~mm}$. This effect tends to increase, especially for shorter beams.

Figure 5 presents the graphs of the values of the critical moment determined for beam IPE300 under uniformly distributed load applied to the top flange. In this case, the highest critical moments are obtained using the Abaqus software (FEM), whereas the lowest (partially divergent from those of larger thickness of the plate) are received from Eq. (2.1) [10]. For instance, for the beam with the span of $L=5 \mathrm{~m}$ and the end-plate $t_{p}=20 \mathrm{~mm}$, Eq. (2.1) produces the critical moment that is $-1.8 \%$ lower from the LTBeam (FEM) value. For the same parameters, the difference between Eq. (6.2) and LTBeam is $+0.1 \%$, whereas between Abaqus and LTBeam it is $+5.1 \%$. As previously, the 
results obtained from Eq. (6.2) practically coincide with those calculated with LTBeam.

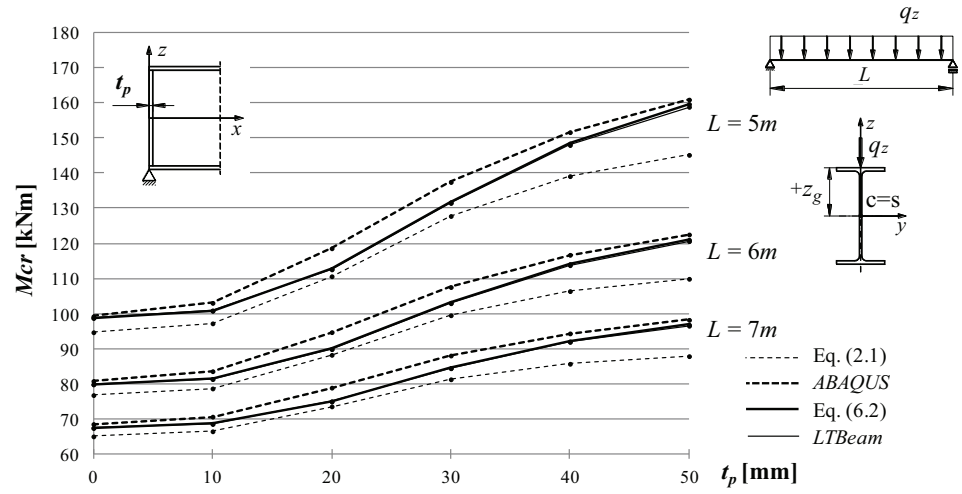

Fig. 5. Comparison of the critical moments for IPE300 beam with the span of $L=5,6,7 \mathrm{~m}$

Figure 6 presents the graphs of the values of the critical moment determined for beam IPE500 under concentrated load applied to the top flange at the mid span. In this case, the highest critical moments are obtained from Eq. (2.1) [10], and the lowest - from LTBeam software (FEM). Equation (6.2) gives the results that are higher than LTBeam ones by approx. $+1.5 \%$, and which on many occasions, coincide with the Abaqus results. For instance, for the beam with the span of $L=8 \mathrm{~m}$ and the end-plate $t_{p}=20 \mathrm{~mm}$, Eq. (2.1) produces the critical moment that is greater by $+4.0 \%$ than that obtained with the use of LTBeam (FEM). For the same parameters, the difference between Eq. (6.2) and LTBeam is $+1.4 \%$, whereas between Abaqus and LTBeam, it is $+1.4 \%$.

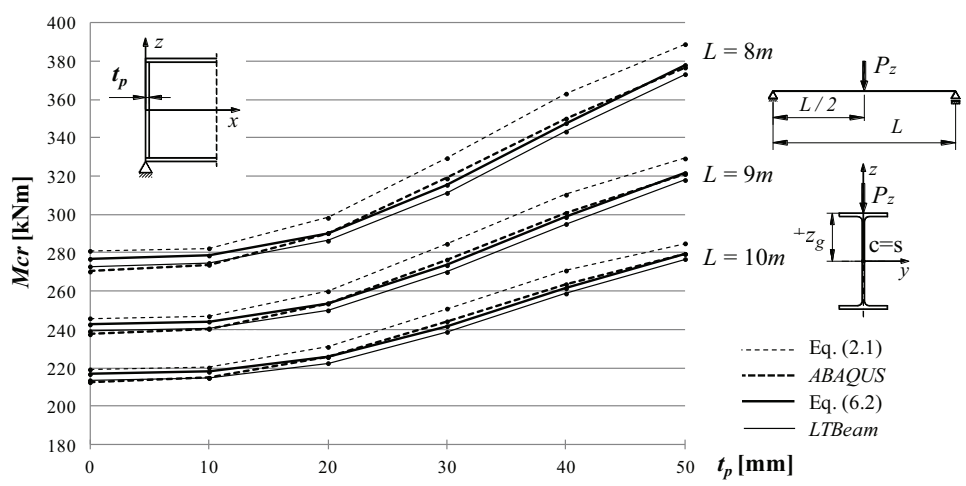

Fig. 6. Comparison of the critical moments for IPE500 beam with the span of $L=8,9,10 \mathrm{~m}$ 
Figure 7 presents the graphs of the values of the critical moment determined for beam IPE500 under uniformly distributed load applied to the top flange. The highest critical moments are obtained using the Abaqus software (FEM), and the lowest are produced from Eq. (2.1) [10]. The values determined from Eq. (6.2) coincide in this case with LTBeam results. For instance, for the beam with the span of $L=8 \mathrm{~m}$ and the end-plate $t_{p}=20 \mathrm{~mm}$, Eq. (2.1) produces the critical moment that is lower by $-2.8 \%$ from the value given by LTBeam (FEM). For the same parameters, the difference between Eq. (6.2) and LTBeam is $+0.1 \%$, and between Abaqus and LTBeam it is $+1.5 \%$.

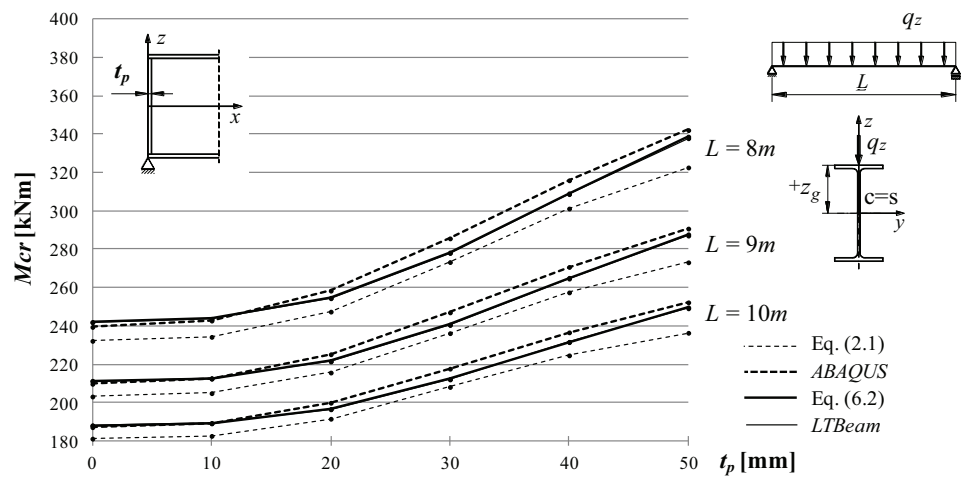

Fig. 7. Comparison of the critical moments for IPE500 beam with the span of $L=8,9,10 \mathrm{~m}$

\section{CONCLUSIONS}

When designing metal structures, it is a good idea to use different methods to verify calculations, especially when the potential reserves of resistance need to be taken into consideration. Then, manual methods (or rather spreadsheets) for estimating the critical moment provide an effective way to verify FEM calculations.

The twist angle function expressed with power polynomials and the energy method make it possible to develop computer programs for the numerical determination of critical moments, and "symbolic" devising of the approximation formulas Eq. $(6.1,6.2,6.3)$. The formulas are obtained using one term (containing "coupled" polynomials $W_{P 1}$ and $W_{U 1}$ ) of the beam twist angle function. The application of the approximation formulas Eq. $(6.1,6.2,6.3)$ makes it possible to estimate, in a relatively simple way, the elastic critical moment of bi-symmetric I-beams stiffened to constrain the warping of the support sections. Formulas are derived for the static diagrams most often found in 
engineering practice.

The comparison of the values of the critical moments indicates good agreement of results between those obtained from Eq. (6.1), (6.2), (6.3) and from FEM (especially LTBeam). When the beam is stiffened with end-plates, Eq. (2.1) [10] also produces a good approximation.

Critical moments (Tables 6 and 7) estimated with formulas, Eq. (6.2), (6.3), provide sufficient engineering approximation when compared with the values obtained with the LTBeam software (FEM). The results produced with $M_{L T B, E L}$ program, which contains three terms of the series Eq. (4.1), show very good agreement of with those obtained with FEM. The application of Eq. (2.1) [10] and FEM (Abaqus, LTBeam) to verify the formula in Eq. (6.2), (Fig. 4, 5, 6, 7) demonstrates good accuracy of results for beams stiffened with the end-plate at supports.

\section{REFERENCES}

1 Bijak R. The lateral buckling moment of simply supported unrestrained symmetric I-shaped beams with free warping (in Polish). XII ICMS Wrocław 2011, 144-151.

2 DIN 18800-2:1990-11. Stahlbauten - Teil 2: Stabilitätsfälle - Knicken von Stäben und Stabwerken.

3 ENV-1993-1-1:1993. Design of Steel Structures - Part 1-1: General Rules for Buildings.

4 Galéa Y. Moment critique de déversement élastique de pouter fléchies. Présentation du logiciel LTBEAM. Revue Construction Métallique. CTICM 2003 (2).

5 Giżejowski M. Lateral buckling of steel beams with limited rotation ability at supports (in Polish). Inżynieria i Budownictwo 10/2001, 589-594.

6 Gosowski B. Spatial stability of longitudinally and laterally braced full-walled members of metal structures (in Polish). Wrocław 1992.

7 Gosowski B. Non-uniform torsion of stiffened open thin-walled members of steel structures. JCSR 63 (2007), 849-865.

8 Gotluru B.P., Schafer B.W., Peköz T. Torsion in thin-walled cold-formed steel beams. Thin-Walled Structures 37 (2000), 127-145.

9 Jakubowski S. Buckling of Thin-Walled Girders under Compound Load. Thin-Walled Structures 6 (1988), 129-150.

10 Lindner J., Gietzelt R. Stabilisierung von Biegeträgern mit I-Profil durch angeschweißte Kopfplatten. Stahlbau 3/1984, 69-74.

11 Pałkowski Sz. Steel structures. Selected issues of calculation and design (in Polish). Warszawa 2009.

12 Pi B.Y.L., Trahair N.S. Distortion and warping at beam supports. Journal of Structural Engineering 2000, Vol. 126, No. 11, 1279-1287.

13 Piotrowski R., Szychowski A. Applying the energy method and polynomials to the determination of the critical buckling moments in beams (in Polish). Konstrukcje betonowe i metalowe, 249-257. Bydgoszcz 2015.

14 Szychowski A. A theoretical analysis of the local buckling in thin-walled bars with open cross-section subjected to warping torsion. Thin-Walled Structures 76 (2014), 42-55.

15 Szychowski A. Stability of cantilever walls of steel thin-walled bars with open cross-section. Thin-Walled Structures 94 (2015), 348-358.

16 Timoshenko S.P., Gere J.M. Theory of Elastic Stability (in Polish). Warszawa 1963. 


\section{LIST OF FIGURES AND TABLES:}

Fig. 1. Beam stiffened with end-plates: a) view, b) section A-A

Rys. 1. Belka usztywniona blachami czołowymi: a) widok, b) przekrój A-A

Fig. 2. Static scheme of the beam: a) view, b) section A-A

Rys. 2. Schemat statyczny belki: a) widok, b) przekrój A-A

Fig. 3. Exemplary beam modelled using the Abaqus software

Rys. 3. Przykładowa belka zamodelowana w programie Abaqus

Fig. 4. Comparison of the critical moments for IPE300 beam with the span of $L=5,6,7 \mathrm{~m}$

Rys. 4. Porównanie momentów krytycznych zwichrzenia dla belki IPE300 o rozpiętości $L=5,6,7 \mathrm{~m}$

Fig. 5. Comparison of the critical moments for IPE300 beam with the span of $L=5,6,7 \mathrm{~m}$

Rys. 5. Porównanie momentów krytycznych zwichrzenia dla belki IPE300 o rozpiętości $L=5,6,7 \mathrm{~m}$

Fig. 6. Comparison of the critical moments for IPE500 beam with the span of $L=8,9,10 \mathrm{~m}$

Rys. 6. Porównanie momentów krytycznych zwichrzenia dla belki IPE500 o rozpiętości $L=8,9,10 \mathrm{~m}$

Fig. 7. Comparison of the critical moments for IPE500 beam with the span of $L=8,9,10 \mathrm{~m}$

Rys. 7. Porównanie momentów krytycznych zwichrzenia dla belki IPE500 o rozpiętości $L=8,9,10 \mathrm{~m}$

Tab. 1. Exemplary ways of beam stiffening used to prevent warping $[6,12]$

Tab. 1. Przykładowe sposoby usztywnienia belek na spaczenie $[6,12]$

Tab. 2. Polynomials used in the study $(\rho=x / L)$

Tab. 2. Zastosowane wielomiany $(\rho=x / L)$

Tab. 3. Coefficients $A_{1}, A_{2}, A_{3}$ for selected loading schemes

Tab. 3. Współczynniki $A_{1}, A_{2}, A_{3}$ dla wybranych schematów obciążenia

Tab. 4. Coefficients $B_{1}, B_{2}, B_{3}, B_{4}$ for selected loading schemes

Tab. 4. Współczynniki $B_{1}, B_{2}, B_{3}, B_{4}$ dla wybranych schematów obciążenia

Tab. 5. Coefficients $C_{1}, C_{2}, C_{3}, C_{4}$

Tab. 5. Współczynniki $C_{1}, C_{2}, C_{3}, C_{4}$

Tab. 6. Comparison of critical moments ( $M_{L T B, E L}$ vs. Eq. (6.2) vs. LTBeam)

Tab. 6. Porównanie momentów krytycznych ( $M_{L T B, E L}$ vs. (6.2) vs. LTBeam)

Tab. 7. Comparison of critical moments ( $M_{L T B, E L}$ vs. Eq. (6.3) vs. LTBeam)

Tab. 7. Porównanie momentów krytycznych ( $M_{L T B, E L}$ vs. (6.3) vs. LTBeam) 


\section{ZWICHRZENIE BELEK SPRĘŻYŚCIE ZAMOCOWANYCH PRZECIW SPACZENIU NA PODPORACH}

Słowa kluczowe: moment krytyczny zwichrzenia, sprężyste zamocowanie przeciw spaczeniu, blachy czołowe, metoda energetyczna, wielomiany potęgowe

\section{STRESZCZENIE:}

Współcześnie stosowane metody projektowania elementów stalowych zmierzają do uwzględnienia szeregu parametrów poprawiających sposób odwzorowania rzeczywistych warunków pracy konstrukcji w inżynierskim modelu obliczeniowym. Jednym z istotnych parametrów jest wpływ sprężystego zamocowania przeciw spaczeniu przekrojów podporowych na moment krytyczny zwichrzenia belek.

W pracy przedstawiono wyniki badań teoretycznych zwichrzenia bisymetrycznych belek dwuteowych sprężyście zamocowanych przeciw spaczeniu na podporach. Uwzględniono często występujące w praktyce schematy obciążenia. Stopień sprężystego zamocowania przeciw spaczeniu opisano współczynnikiem $\varepsilon$ wg wzoru $(3.1)[8,12]$ uwzględniającym sztywność sprężystego zamocowania $\alpha_{w}$ wg wzoru (3.2) [8,12]. Współczynnik sprężystego zamocowania zmienia się od $\varepsilon=0$ dla zupełnej swobody spaczenia, do $\varepsilon=\infty$ dla pełnej blokady spaczenia. W pracy wprowadzono dodatkowo bezwymiarowy wskaźnik utwierdzenia $\kappa$ wg wzoru (3.3), zmieniający się od $\kappa=0$ dla zupełnej swobody spaczenia do $\kappa=1$ dla pełnej blokady spaczenia.

Do wyznaczenia momentu krytycznego zastosowano metodę energetyczną. Funkcję kąta skręcenia $\varphi(x)$ zawierającą trzy wyrazy szeregu (4.1) opisano „sprzężonymi” za pomocą wskaźnika $\kappa$ wielomianami potęgowymi o prostej interpretacji fizycznej (tab. 2). Na podstawie równania (5.1) opracowano w środowisku pakietu Mathematica ${ }^{\circledR}$ program obliczeniowy McrLT_elastic_fix.on.warp.nb., w skrócie $M_{L T B, E L}$. Program umożliwia wyznaczenie momentów krytycznych zwichrzenia sprężyście zamocowanych na spaczenie bisymetrycznych belek dwuteowych dla dowolnych parametrów geometrycznych przekroju i schematów obciążenia zamieszczonych w tabelach 3, 4 i 5 oraz dowolnej wartości współrzędnej $\left(z_{g}\right)$ (rys. 2) punktu przyłożenia obciążenia poprzecznego.

Ponadto wyprowadzono wzory aproksymacyjne do szacowania momentów krytycznych zwichrzenia sprężyście zamocowanych przeciw spaczeniu na podporach, belek o bisymetrycznym przekroju dwuteowym, dla tych samych schematów obciążenia. W tym celu opracowano w pakiecie Mathematica ${ }^{\circledR}$ program McrLT_elastic_fix.on.warp._ sym.cal.nb do obliczeń symbolicznych. W tym przypadku funkcję kąta skręcenia aproksymowano tylko pierwszym wyrazem szeregu (4.1) z zastosowaniem „sprzężonych” wielomianów: $W_{P I}$ i $W_{U l}$ (tab. 2). Pozwoliło to na wyprowadzenie stosunkowo prostych wzorów aproksymacyjnych (6.1), (6.2) i (6.3) na momenty krytyczne zwichrzenia belek dla dowolnej wartości wskaźnika utwierdzenia na spaczenie $\kappa$ przekrojów podporowych.

Uzyskane w pracy wyniki obliczone programem McrLT_elastic_fix.on.warp.nb. oraz za pomocą wzorów aproksymacyjnych porównano z obliczeniami MES (LTBeam i Abaqus).

Z porównania momentów krytycznych wyznaczonych programem $M_{L T B, S P R}$, zawierającym trzy wyrazy szeregu (4.1), wynikła bardzo dobra zgodność wyników w stosunku do MES (LTBeam), różnice nie przekroczyły +0,5\% (tab. 6, 7). Momenty krytyczne oszacowane za pomocą wzorów (6.2) i (6.3) dały również wystarczające przybliżenie inżynierskie w stosunku do wartości uzyskanych z programu LTBeam (tab. 6, 7; kol. 8). 
Maksymalne różnice nie przekroczyły $+1,4 \%$ (tab. 6 ) oraz $+3,1 \%$ (tab.7).

Szczegółowe obliczenia momentu krytycznego przeprowadzono dla belek wzmocnionych blachami czołowymi w przekrojach podporowych. Belki obciążano siłą skupioną w środku rozpiętości lub obciążeniem równomiernie rozłożonym na całym przęśle. Obciążenia przykładano do półki górnej kształtownika. Otrzymane ze wzoru (6.2) wyniki porównano z wartościami uzyskanymi z literatury (2.1) [10] oraz MES (Abaqus, LTBeam). We wszystkich przypadkach otrzymano dobrą z punktu widzenia obliczeń inżynierskich zgodność wyników (rys. 4, 5, 6, 7).

W projektowaniu konstrukcji metalowych warto stosować różne metody weryfikacji obliczeń, zwłaszcza dla przypadków uwzględniających potencjalne zapasy nośności. W tym przypadku ręczne (lub raczej zapisane w arkuszach kalkulacyjnych) metody szacowania momentów krytycznych zwichrzenia mogą stanowić skuteczne sposoby weryfikacji obliczeń MES. 